RJPSSs, Vol. XLVI No.1, June 2020 ISSN: (P)0048-7325 (e) 2454-7026 Impact Factor 7.821 (SJIF)

https://doi.org/10.31995/rjpsss.2020v46i01.10

\title{
Digital Learning Solutions to Improve Teacher Education
}

Dr. Vinita,

Assistant Professor,

Dept. of Education,

Meerut College, Meerut

E-mail:vinitasinghccsu@gmail.com
Nidhi Chauhan, Associate Professor, S.S.V. P.G. College, Hapur nidhichauhan2r@gmail.com

\section{Abstract}

"The power to change education for better or worseis and always has been in hands of teachers."

Judith Lloyd Yero, 2003

This paper is about to know the current awareness of teachers about digital learning. Digital learning is any type of learning that is facilitated by technology or by instruction practice that makes effective use of technology. In the present time student is very active and advanced. They need democratic digital environment to learn instead of traditional repression system. The teacher should be well trained with the new technology and use them to make their teaching learning effective. Digital technology are electronic tools, systems, device and resources that generate, store or process data. The paper check the level of awareness of the teacher and suggest the measure to improve their teaching learning process through digitalization. So by implement of digital learning teacher can improve their teaching skill and can innovative. It is an attractive technology. By the use of this methodology teacher can use of their skill in the class room situation and also trained students for their occupation and social life. It removes the traditional method of teaching and prepare teacher to apply modern method of teaching by the help of digital learning the quality of teacher education will be improved.

Keywords: Digital learning, Digital technology, teacher education, awareness.
Reference to this paper should be made as follows:

Received: 20.05.2020

Approved: 30.06 .2020

Dr. Vinita

Nidhi Chauhan

Digital LEarning Solutions

TO IMPROVE TEACHER

EDUCATION

RJPSSs 2020, Vol. XLVI,

No. 1, pp. 85-92

Article No.10

Online available at: http://

rjpsss.anubooks.com/

https://doi.org/10.31995/

rjpsss.2020v46i01.10 
DigItal LEARNING SOLUTIONS TO IMPROVE TEACHER EDUCATION

Dr. Vinita, Nidhi Chauhan,

\section{Introduction}

Today, digital learning are becoming very significant in education and training. New information had been developed in teaching and learning. Digital learning is any type of learning that is facilitated by technology or by instructional practice that makes effective use of technology. Digital learning occurs across all learning area and domains. It encompasses the application of wide spectrum of practices including.

1 Blended and virtual learning.

2 Game based learning

3 Accessing digital content

4 Collaborating locally and globally

5 Assessment and reporting online

6 Active participation is online communities.

7 Using technology to connect, collaborate, curate and create.

Digital learning is an umbrella term that is often used to encompass a few other commonly used terms and concepts within our industry, including e-learning, m-learning and social learning. Digital learning is learning facilitated by technology that gives students some element of control over time, place, path or pace. Digital learning is more than just providing students with a laptop. Digital learning requires a combination of technology, digital content and instruction. Digital learning refers to the process of learning with the aid of digital content, platform or facilitators. The future of learning would see an increased use of digital components increasingly as mere content becomes available, the comfort and willingness of the players in the learning ecosystem changes along with their mind set and pedagogy evolves to leverage the value proposition of digital learning.

Teacher education is well known that the quality and extent of learner achievement are determined primarily by teacher competence, sensitivity and teacher motivation. The National Council for Teacher Education has defined teacher education as -a programme of education, researcher and training of persons to teacher from pre-primary to higher education level. Teacher education is a programme that is related to the development of teacher proficiency and competence that is related to the development of teacher proficiency and competence that would enable and empower the teacher the teacher to meet the requirements of the profession and face the challenges therein. Digital learning in teacher education can be explained as,

1 To improve Teaching Skill. 
RJPSSs, Vol. XLVI No.1, June 2020 ISSN: (P)0048-7325 (e) 2454-7026 Impact Factor 7.821 (SJIF)

https://doi.org/10.31995/rjpsss.2020v46i01.10

2 Effectiveness of Classroom

3 Innovative Teaching

4 Enhance Active Learning of Teacher Trainees.

5 Improving Professional Development

6 Improving Education Management

Awareness may also refer to public or common knowledge or understanding about a social, scientific, or political issue. Awareness is the ability to directly know and perceive, to feel, or to be conscious of events, objects, thoughts, emotions, or sensory patterns. In this level of consciousness, sense data can be confirmed by an observer without necessarily implying understanding. More broadly, it is the state or quality of being aware of some thing. In biological psychology, awareness is defined as a human's or an animals perception and cognitive reaction to a condition or event.

"A person with awareness would likely be able to report or her internal and external states."

\section{Objective of the Study}

1 To explore the level of awareness about the use of digital learning among teacher educators for digital learning solutions.

2 To study the impact of awareness of digital learning among teacher educators for digital learning solutions.

3 To suggest the measure to improve teaching learning process of teacher educators.

\section{Hypothesis of the Study}

1 The teacher educations having awareness about digital learning.

2 Teacher educators having high level awareness of digital learning in comparison to using the digital learning in teaching process.

\section{Need \& Significance of the Study}

The present study is related to awareness of teacher educators about digital learning. If the educators have the knowledge of digital learning their teaching become more effective. But if teacher educators have not used their awareness in teaching process, the quality level will be decrease in students. They can use their awareness to train future teachers. They trained the trainees according to study requirement. By this the quality of teacher education will be improved. This paper check the level of awareness to improve their teaching learning process through digitalization.

\section{Methodology}

Methodology is the main process of the study. The present study distinction 
the Digital learning solutions to improve the teacher education. Various research strategies are available for conducting research study as historical, philosophical, exploratory, case study. But the choice of method of research is controlled by considerations like purpose of study, objectives, hypothesis used to survey method. Because this method is one of the most commonly used approaches to educational problem. It is concerned with the present study.

It is relatively more scientific and accurate. It provides more accurate data. Data is essentially an important part of the research process. So that the inferences, hypotheses or generalizations tentatively held may be identified as valid verified, corrected, accepted or rejected keeping in mind the objectives. The method of this study is most appropriate.

\section{Population and Sample of the Study}

In the present study, the requirement of representative has ensured by adopting random sampling technique for the selection of samples. A sample of 100 teachers educators working in teacher training institutes was selected for the study. The data was selected for the study. The data was selected using Random Sampling on interview basis. Distinction as made only higher education teacher in the sample. No distinction was made based on types of management i.e. Government, private colleges. Directional way of hypothesis has been selected for this paper.

\section{Variables Used in the Study}

1 Digital Learning

2 Digital Technology

3 Teacher Education

4 Awareness

\section{Data Gathering Tools}

A self develop questionnaire belong to find the awareness of digital learning among teacher educators is used as a tool for this study. The advantage of using questionnaire is that the items in it can be measured in a very standard way, to which various statistical techniques can be used. The teacher educators gave their opinion on the statement in the form of yes or no.

For respondent data collected with researcher help by giving her complete information about questionnaire. All respondent give opinion for statement.

\section{Technique Used to the Study}

A survey was undertaken to collect quantitative data to be analyzed statistically and make assertion about it. Purposive samples were drawn from the 
population.

The choice of statistical technique depended upon the nature of the distribution of scores and the hypothesis to be tasted. After collecting data hypothesis wise, it was subjected to appropriate statistical treatment. As the present study aims at studying the impact of awareness of digital learning solution among the teacher educators. ' $t$ ' test and percentage analysis was thought of as the most appropriate statistical technique. Which has been used to analysis the data.

' $t$ ' test

' $\mathrm{t}$ ' test is statistical test that allows the investigator to compare two means to determine probability that the difference between the means is a real difference rather than a chance difference. It involves the computation of the ratio between observed variance and error variance the sampling factor.

For using ' $\mathrm{t}$ ' test the following formula has been used -

$$
\mathrm{t}=\frac{\text { Difference between the means }}{\text { Standard error of difference }}
$$

$$
\mathrm{t}=\frac{\mathrm{M}_{1} \sim M_{2}}{\sqrt{\left(\frac{\sigma_{1}^{2}}{\mathrm{~N}_{1}}\right)+\left(\frac{\sigma_{2}^{2}}{\mathrm{~N}_{2}}\right)}}
$$

Where

$\mathrm{M}_{1}=$ Mean of the first group

$\mathrm{M}_{2}=$ Mean of the second group

$=$ Standard deviation of the first group

${ }_{2}=$ Standard deviation of the second group

$\mathrm{N}_{1}=$ Number of cases in the first group

$\mathrm{N}_{2}=$ Number of cases in the second group

Degree of freedom has been calculated as follows

$\mathrm{df}=\mathrm{N}_{1}+\mathrm{N}_{2}-2$

The significance of ' $t$ ' ratio was tested in this study to know whether the mean scores of two groups differ significantly each other or only due to chance error. 
Digital LEARNING SOLUTIONS TO IMPROVE TEACHER EDUCATION

Dr. Vinita, Nidhi Chauhan,

\section{Analysis of Data}

In this study, the statistical analysis of the survey responses is presented and discussed. The main objectives of this study is to study the explore \& impact of awareness of digital learning by teacher educators. There are a comparison the awareness of Digital learning of teacher educators in using the digital learning in teaching process. The generalization and interpretation leads towards conclusions and suggestions. It is very necessary to get a meaningful picture of the raw information collected. It involved the process of interpretation. On the basis of collected data ' $t$ ' test is used for analysis of data. The data is being analyzed and interpreted in the light of set hypothesis.

\section{Interpretation of Data}

Hypothesis 1 states that the teacher educators having awareness about digital learning.

Table showing level of awareness about the digital learning among teacher educators.

\begin{tabular}{|l|c|c|}
\hline \multicolumn{1}{|c|}{$\begin{array}{c}\text { Category of Awareness About Digital } \\
\text { Learning }\end{array}$} & \multicolumn{2}{c|}{ Teacher Educators } \\
\cline { 2 - 3 } & N & Percentage(\%) \\
\hline Very High & 8 & 8 \\
\hline High & 12 & 12 \\
\hline Average & 52 & 52 \\
\hline Low & 18 & 18 \\
\hline Very Low & 10 & 10 \\
\hline
\end{tabular}

\section{Finding}

Table shows that the data was analyzed with the help of percentage anlaysis and was performed of teacher educators. The result indicate that mostly teacher educators possess average level of awareness and few teacher educators passes high level of awareness. This indicates that a digital learning solution program should be conducted to improve teacher education and explore the awareness in teacher educators for digital learning solutions in teacher education.

Hypothesis 2 state that the teacher educators having high level awareness of digital learning in comparison to using the digital learning in teaching process.

\begin{tabular}{|c|c|c|c|c|c|}
\hline $\begin{array}{l}\text { Name of the } \\
\text { Group }\end{array}$ & $\begin{array}{l}\text { Number of } \\
\text { Teacher } \\
\text { Educators }\end{array}$ & Mean & SD & 't' Value & $\begin{array}{c}\text { Significant } \\
\text { level }\end{array}$ \\
\hline $\begin{array}{ll}\text { Awareness } & \text { of } \\
\text { digital learning } & \end{array}$ & 62 & 9.11 & 7.00 & \multirow{2}{*}{3.32} & Significant \\
\hline $\begin{array}{l}\text { Using of digital } \\
\text { learning }\end{array}$ & 38 & 5.45 & 4.00 & & \\
\hline
\end{tabular}


RJPSSs, Vol. XLVI No.1, June 2020 ISSN: (P)0048-7325 (e) 2454-7026 Impact Factor 7.821 (SJIF)

https://doi.org/10.31995/rjpsss.2020v46i01.10

\section{Finding}

Table showing that obtained $(\mathrm{t})$ value is 3.32 and table value of $(\mathrm{t})$ for $\mathrm{df} 98$ at 0.05 level is $1.98 \& 0.01$ level is 2.63 . So the value is higher on both the level of significance, Sohypothesis is selected. It means the teacher educators having high level awareness of digital learning in comparison to using the digital learning in teaching process.

This indicates that a digital learning solution program should be conduct to modify and suggest the awareness of teacher educators through digital learning. Positive atmosphere and tools will be provide teacher educator so that they can use digital learning process in their teaching process.

\section{Implication of the Study}

The present study has its implication that in present time awareness of digital learning among teacher educators is most important. A nation, a society can be developed only when the students of the society will be educated. If the teacher educator will be aware about the digital learning solution it will give a positive effect in teacher education. So by implement of digital learning teacher can improve their teaching skill and can innovative. It is an attractive and effective technology.

\section{Conclusion}

The conclusion was drawn that the teacher educator having awareness about digital learning but they can notusing the digital learning in the teaching process. So the digital learning solution in teacher education is necessary. Positive atmosphere and tools will be provide teacher educator so that they can use digital learning process in their teaching process.

\section{Suggestion for Further Study}

1 The present study can be replicate at school teacher.

2 Similar study may be done on a large sample.

3 More independent variable can be included in the study.

4 The present study may be done separately on teacher educator.

\section{References}

1 Venkataian N “Educational Technology” Atul Publishers Darya Ganj. New Delhi.

2 Role of ICT in teacher education - YjosephineJoyamani, S Pitchammal R. Niranjana Devi.

3 Chauhan S.S. Innovation in Teacher and Icarning Process New Delhi Vikas Publishign House Pvt Ltd.

4 Mishra, R.C. Teaching of Information Technology Aph Publishing Corporation, 
DIGITAL LEARNING SOLUTIONS TO IMPROVE TEACHER EDUCATION

Dr. Vinita, Nidhi Chauhan,

New Delhi.

5 Passi B.K. Professional Development and ICT in Education.

6 Bansal Harish Modern Methods of Teacher Training, A.P.H. Publishing House.

7 N. Ramnath Kishan Global Trends in Teacher Education A.P.H. Publishing House.

8 Weiner, B. (1990). The History of Motivational Research, Journal of Educational Psychology, Vol. 82. (4) 616-627.

9 Woodrow, J. (1990) Locus of Control and Student Teacher Computer Attitudes. Computers Educ. Vol. 14. No. 4 pp. 421-432. 